\title{
Geologic Map of the Priest Rapids 1:100,000 Quadrangle, Washington
}

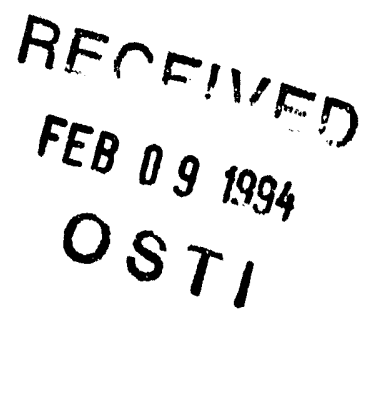

Fiepared for the U.S. Department of Energy Cifitie of Environmental Restoration and Waste Management

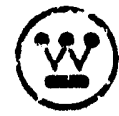

Westinghouse

Hanford Company Richland, Washington 99352

Hanford Operztions and Engineering Contracior for the

ij.S. iJepanment of Enerúy under Contract DE-AC06-87RL10930 
LEGAL DISCI.AIMER

This reporl was prepared as an accejnl of work sponsored by an agency of the United Slates Government. Neither the United Stales Government rior any agericy thareof, nor any of their employeas, ricr any of their contiactors, subconitractors or their employees, makes any warraniy, express or implied, or assumes any legal liability or responsibility for the accuracy, completeness, or any third party's use or the results of such use of any intormation, apparatus, product, or process disclosed, or represents that its use would not infringe privately owned righis. Relerence herein to ar.y specific commercial product, process, or service by trade name, trademark, manufacturer, or otherwise, does not necessarily consturute or imply its endorsement, recommendation, or tavoring by the Uniteo States Government or any agency thereof or its contractors or subcontraclors. The views and opinions of authors expressed herein do nol necessariiy state or reflect those of the Uniteo States Government ur any agency thareot.

This icpent has beon reproduced from the best available copy. Ava!lable in peper copy and microliche.

Avaiiable to the U.S. Department of Eriergy

and its conizactors from

Orfica of Scientific and Technical Information

P.O. Box 62

Oak. Ridge, TN 3783 !

(615) 576.8401

Availabla is the public from the U.S. Deparimant of Commerce Nationa! Tcchnical Intormation Service

5295 Porl Hoyal Road

springliald VA $2 \geqslant 161$

(703) 487.4650

Pirilod in the Unitod Stales ol Amotica

Ciscid.i.CHF :I.91) 


\section{Geologic Map of the Priest Rapids 1:100,000 Quadrangle, Washington}

S. P. Reidel

K. R. Fecht

Date Published

September 1993

Prepared for the U.S. Department of Energy Office of Environmental Restoration and Waste Management

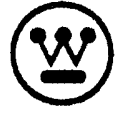
Westinghouse Hanford Company Richland, Washington 99352

Hanford Operations and Engineering Contractor for the

U.S. Department of Energy under Contract DE-AC06-87RL10930 


\title{
GEOLOGIC MAP OF THE PRIEST RAPIDS 1:100,000 QUADRANGLE, WASHINGTON
}

\author{
compiled by \\ Stephen P. Reidel and Karl R. Fecht
}

\section{INTRODUC'TION}

This map of the Priest Rapids 1:100,000-scale quadrangle, Washington, shows the geology of one of fifteen complete or partial 1:100,000-scale quadrangles that cover the southeast quadrant of Washington. Geologic maps of these quadrangles have been compiled by geologists with the Washington Division of Geology and Earth Resources (DGER) and Washington State University and are the principal data sources for a $1: 250,000-$ scale geologic map of the southeast quadrant of Washington, which is in preparation. Eleven of these quadrangles are being released as DGER open-file reports (listed below). The map of the Wenatchee quadrangle has been published by the U.S. Geological Survey (Tabor and others, 1982), and the Moses Lake (Gulick, 1990a), Ritzville (Gulick, 1990b), and Rosalia (Waggoner, 1990) quadrangles have already been released.

The geology of the Priest Rapids quadrangle has not previously been compiled at 1:100,000 scale. Furthermore, this is the first 1:100,000 or smaller scale geologic map of the area to incorporate both bedrock and surficial geology.

This map was compiled in 1992, using published and unpublished geologic maps as sources of data. Except for Swanson and others (1980), source maps with scales smaller than 1:125,000 were not used. Maps produced before 1979 were not used as sources of data for the Columbia River Basalt Group because prior to that year mappers generally did not use geochemistry or magnetic polarity to confirm assignment of basalt flows to stratigraphic units, nor did they employ the stratigraphy that was proposed by Swanson and others (1979) and, with subsequent modifications, is universally used today. The lack of consistent, reliable identification procedures and standardized nomenclature makes it difficult to use pre-1979 maps unless one is personally familiar with the geology. However, as noted below, maps issued before 1979 were used as data sources for geologic units younger than the Columbia River Basalt Group. Figure 2 includes maps that were not used in compiling the geology shown in this report. These maps are included in an attempt to make the sources-of-data listing exhaustive and to inform the reader that these sources of data were not overlooked.

Extensive unpublished geologic mapping by S.P. Reidel, and K.R. Fecht with assistance by M.A. Chamness for the entire map has been incorporated in this map. 
Large-scale maps that show both bedrock and surficial geology were used to compile both bedrock and surficial geology. These maps are:

- sheet 5 of Grolier and Bingham (1971) (used for postbasalt geology and basalt outcrop areas; contacts between members of the Columbia River Basalt Group are from Myers and others (1979) and Reidel (1987).

- For areas of Columbia River Basalt Group outcrop north of the Saddle Mountains, details were taken from the 1:250,000scale geologic map of Swanson and others (1980).

All K-Ar ages cited herein (Baksi, 1989; Tolan and others, 1989; Mckee and others, 1977; Reidel and Fecht, 1987) were published after 1976, they are assumed to have been calculated using the decay and abundance constants adopted by the International Union of Geological Sciences in 1976 (Dalrymple, 1979). The actual constants used were not reported.

The geologic time scale devised for the "Correlation of Stratigraphic Units of North America (COSUNA)" project of the American Association of Petroleum Geologists (Salvador, 1985) is used in this report, with modifications: the Oligocene-Eocene boundary is set at $35.7 \mathrm{Ma}$ (Montanari and others, 1985), and the Pleistocene-Pliocene boundary is set at $1.6 \mathrm{Ma}$ (Aguirre and Pasini, 1985).

\title{
Acknowledgments
}

Support for Reidel was provided by US Department of Energy, Office of Basin Energy Sciences grant number DE-FG06-91ER14172 to S. P. Reidel at Washington State University.

\section{DESCRIPTIONS OF MAP UNITS}

\author{
Sedimentary Deposits and Rocks
}

Quaternary Sedimentary Deposits

Qd

Dune sand (Holocene)--Eolian medium to fine sand and silt; grains composed of quartz, basalt, or feldspar; volcanic ash common; active and stabilized dunes occur in the west and northwest part of the map area; age. inferred from geomorphology and ages of parent materials. Description compiled from: Grolier and Bingham, 1971; Myers and others,.1979; Rigby and others, 1979.

Qda

Active sand dunes. 
Qds

Stabilized sand dunes.

Qa

Alluvium (Holocene to Pleistocene)--Ciay, silt, sand, and gravel deposits of varied thickness and sorting; varied composition, commonly including reworked loess, Ellensburg Formation sediments, and basalt; includes Mazama tephra at numerous places; occurs in valley bottoms throughout the map area; age inferred from geomorphology, ages of parent materials, and the presence of Mazama tephra (about $7 \mathrm{ka}$; Kittleman, 1973, p. 2958). Description from Myers and others, 1979.

QIs

Mass-wasting deposits (Holocene to Pleistocene)--Landslide deposits, talus, and colluvium; found at the base of slopes and on lower parts of slopes; age inferred from geomorphology, stratigraphic position, and ages of parent materials. Description compiled from: Grolier and Bingham, 1971; Myers and others, 1979; Rigby and others, 1979.

Q1

Loess (Holocene to Pleistocene)--Eolian silt and fine sand; tan to gray tan to pale orange; grain size decreases to the northeast; includes tephra beds, caliche layers, and paleosols; thickness as much as $75 \mathrm{~m}$ near St. John and Wilcox northeast of the map area (Ringe, 1970); uppermost loess locally contains Mazama tephra (Foley, 1982, p. 90), about 7 ka (Kittleman, 1973, p. 2958); paleomagnetic measurements show that the oldest loess was deposited during the Matuyama Reversed polarity epoch and is at least $730 \mathrm{ka}$ and probably $1 \mathrm{Ma}$ or older (McDonald and Busacca, $1989, \mathrm{p} .338)$. Includes Palouse Formation. Description compiled from: Grolier and Bingham, 1971; Myers and others, 1979; Rigby and others, 1979.

Qta

Talus deposits. 
Qaf

Alluvial fans (Holocene to Pleistocene)--Sand and gravel of varied lithologies; formed where intermittent tributary streams enter the valley of a master stream; generally cone-shaped; in places overlain by loess; located at the margins of modern stream valleys in the snake River and along the Columbia River in the southwest corner of the map area; age inferred from geomorphic form and ages of parent materials; those fans located at elevations below the maximum elevation of glacial Lake Missoula outburst flooding are younger than the outburst flood deposits and are, therefore, Holocene; those located above the maximum elevation of glacial Lake Missoula outburst flooding are Holocene or older. Description compiled from: Myers and others, 1979; Rigby and others, 1979.

Qfs

Outburst flood deposits, consists of two facies - silt and sand; (Pleistocene)--Lacustrine silt and fine sand; predominantly quartz and feldspar; rhythmically bedded, with stringers of coarse-grained sand and gravel, small-scale cross-bedding, icerafted cobbles, and ice-melt structures present locally; sand dominated facies - plane lamination, occasional channel fill sequences, silt dominated facies - planar laminated and ripple cross laminated, commonly displaying normal graded rhymites; discrete ash layers common; divided into 4 time stratigraphic units based on magnetic polarity, presence of ash beds, pedogenic carbonate development, and stratigraphic position; deposited by outburst floods from glacial Lake Missoula and found along the Snake and Columbia Rivers and to elevations of approximately $1,200 \mathrm{ft}$, but generally not extensive above about $900 \mathrm{ft}$; up to 6 $m$ thick west Cold creek flood bar and south of Gable Mountain; thought to be younger than about $19 \mathrm{ka}$ and older than about $11 \mathrm{ka}$ on the basis of ${ }^{14} \mathrm{C}$ determinations that constrain the ages of advance and retreat of the Columbia lobe in southernmost British Columbia (Waitt, 1980, p. 675); additionally, Mount St. Helens S tephra, with an isotopic age estimate of $13 \mathrm{ka}$ (Mullineaux and others, 1978, p. 178), occurs below the top of the unit (Waitt, 1980, p. 667). Consists of the Touchet Beds. Description compiled from: Grolier and Bingham, 1971; Myers and others, 1979; Rigby and others, 1979.

$\mathrm{Qfs}_{4}$

Younger outburst flood deposits from ice dams in Canada. Glacier Peak ash found in some areas.

$\operatorname{Qfs}_{3}$

Normal polarity; contains Mt. St. Helens set $S$ ash. $\mathrm{Qfs}_{2}$ 
Normal polarity, U/Th age date of $200 \pm 70 \mathrm{ka}$, capped by pedogenic carbonate development (stage III or IV).

$\operatorname{Qfs}_{1}$

Oldest outburst deposits; reversed magnetic polarity, age $770 \pm 20 \mathrm{ka}$ based on magnetic polarity.

Qfg

Outburst flood deposits, gravel (Pleistocene)--Gravels; clasts range from sand to boulders, size generally decreasing away from major Missoula flood current channels; clasts chiefly basalt, but include granite, quartzite, diorite, and porphyries; divided into 4 time stratigraphic units based on magnetic polarity, presence of ash beds, pedogenic carbonate development, and stratigraphic position; deposited by outburst floods from glacial Lake Missoula and display numerous bedding forms and large flood bars; found along the Snake and Columbia Rivers; same age as outburst flood deposits, silt and sand (unit Qfs above) and correlative with Touchet Beds. Description compiled from: Grolier and Bingham, 1971; Myers and others, 1979; Rigby and others, 1979; this report.

$\operatorname{Qfg}_{4}$

Younger outburst flood deposits from ice dams in Canada. Glacier Peak ash found in some areas.

$\operatorname{lfg}_{3}$

Normal polarity; contains Mt. St. Helens set $S$ ash.

$\mathrm{Qfg}_{2}$

Normal polarity, U/Th age date of $200 \pm 70 \mathrm{ka}$, capped by pedogenic carbonate development (stage III or IV).

$\operatorname{lfg}_{1}$

Oldest outburst deposits; reversed magnetic polarity, age $770 \pm 20 \mathrm{ka}$ based on magnetic polarity. 


\section{Tertiary Sedimentary Deposits}

Ringold Formation

The Ringold Formation consists of fine and coarse, semiindurated, fluvial and lacustrine deposits in and near the Pasco Basin (Fecht and others, 1987; Lindsey, 1991). In the Priest Rapids 1:100,00' quadrangle this unit crops out mainly along the Columbia and Snake Rivers but also occurs along the north side of the Saddle Mountains The formation is as thick as $185 \mathrm{~m}$ in the deepest part of the Cold Creek syncline at the Hanford Site. The unit is overlain by unconsolidated Pliocene and Pleistocene deposits and underlain by the Ice Harbor Member of the saddle Mountains Basalt (Fecht and others, 1987), which was dated at 8.5 Ma by McKee and others (1977). At the white Bluffs north of Pasco, the lower $20 \mathrm{~m}$ of the Ringold has normal magnetic polarity, and the upper $100 \mathrm{~m}$ has reversed polarity (Rigby and others, 1979, p. 16). Microtine (rodent) fossils and magnetic polarity data indicate that the unit is older than $3.4 \mathrm{Ma}$ (Fecht and others, 1987). Three facies are shown on the map: finer deposits $\left(P_{L} A_{C}\right)$, coarser sediments, chiefly conglomerate $\left(P_{L} A_{C g}\right)$, and Alluvial fan deposits ( $P_{L}$ Maf).

$\mathrm{P}_{L^{\mathrm{MC}}}$

Continental sedimentary deposits' (Pliocene to Miocene)-Interbedded white, gray, green, red, or tan sand, silt, and clay beds with local pebble lenses and stringers; silty clay units horizontally laminated and generally lacking current-generated sedimentary structures; silt and sand units display horizontal, ripple, and cross bedding; sand chiefly quartz and feldspar; commonly capped by caliche; contains diatomite beds, ash beds, and fossils. Consists of the finer facies of the Ringold Formation. Description compiled,from: Myers and others, 1979; Rigby and others, 1979.

\section{$\mathrm{P}_{\mathrm{I}^{\mathrm{ACg}}}$}

Conglomerate (Pliocene to Miocene)--Varicolored pebble to cobble conglomerate with sand matrix; clasts well rounded and chiefly composed of quartzite, granite, basalt, metamorphic rocks, and porphyritic volcanic rocks; generally massively bedded with some imbrication; includes lenses of coarse to medium quartz and feldspar sand that are cross bedded or foreset bedded in places; commonly uncemented, but in places moderately to poorly indurated with silica, iron oxide, and calcite. Consists of the conglomeratic facies of the Ringold Formation. 
WHC - MR - 0442

$P_{L}$ Maf

Fanglomerate (Pliocene to Miocene)--Pebble to cobble fanglomerate, subangular to angular basalt fragments and Ellensburg sediments ranging in size from cobble to medium grained sand. Variably indurated with pedogenic carbonate. Generally poorly bedded, includes fluvial, mass wastage, and landslide deposits. Description compiled from: Myers and others, 1979; Rigby and others, 1979.

\section{Tertiary Volcanic Rocks}

\section{Columbia River Basalt Group}

The Columbia River Basalt Group in Washington is composed of four formations. From top to bottom they are the saddle Mountains Basalt, the Wanapum Basalt, the Grande Ronde Basalt, and the Imnaha Basalt. The upper three formations crop out in the Priest Rapids 1:100,000-scale quadrangle.

Saddle Mountains Basalt

$\mathrm{Av}_{\mathrm{sih}}$

Ice Harbor Member (upper Miocene)--Basalt flows, vents, northwest-trending feeder dikes, and minor tephra; plagioclase phenocrysts commonly more tabular (needlelike in cross section) than in other saddle Mountains Basalt flows; less than $30 \mathrm{~m}$ thick in most places; flows crop out along the lower reaches of the Walla Walla and Touchet Rivers, in the Snake River valley near Ice Harbor Dam, along the Columbia River near Wallula Gap, and a few miles northwest of Ice Harbor Dam; about $8.5 \mathrm{Ma}$, based on $\mathrm{K}-$ Ar age estimates (McKee and others, 1977); consists of three informal units (Swanson and others, 1975, 1980; Swanson and Helz, 1979), from youngest to oldest, basalt of Goose Island, basalt of Martindale, and basalt of Basin City, described by Myers and others (1979) and Swanson and others (1980) as follows:

Basalt of Goose Island--Dark gray, tan-weathering basalt flows with scattered phenocrysts of plagioclase (2-10 $\mathrm{mm}$ long), pyroxene (2 $\mathrm{mm}$ long), and olivine and magnetite (less than $5 \mathrm{~mm}$ across); plagioclase-pyroxene glomerocrysts 1-3 cm in diameter; microvesicular entablature with brickbat jointing; well-formed colonnade with 0.5-1.5-m-diameter columns; low-latitude normal (transitional) magnetic polarity (Choiniere and Swanson, 1979); crops out near and a few miles nurthwest of Ice Harbor Dam; feeder dikes near Ice Harbor Dam, near Reese in the Walla Walla River valley, and in Esquatzel Coulee just northwest of the map area.

Basalt of Martindale--Two or more, black to gray, reddish-weathering, fine-to medium-grained, vesicular to. 
microvesicular basalt flows with sparse to abundant augite, plagioclase, and olivine phenocrysts; locally abundant glomerophyric clots of plagioclase and augite $20 \mathrm{~mm}$ or more in diameter; lower flow has. a thick scoria top and a welldeveloped entablature overlying a poorly developed colonnade with columns as much as $1.5 \mathrm{~m}$ in diameter; reversed magnetic polarity (Choiniere and Swanson, 1979); upper flow or flows are less phyric and lack glomerophyric clots (Swanson and Helz, 1979); crops out near Ice Harbor Dam, near Wallula Gap, and in the lower reaches of the Touchet and Walla Walla River valleys; dikes and vents upstream and downstream of Ice Harbor Dam. A basalt of Martindale vent has been identified on the south side of the Olympic-Wallowa lineament along line with other Martindale vents (Reidel and Tolan, written comm., 1993).

Basalt of Basin City--Gray to black, fine-grained basalt flows; plagioclase phenocrysts generally less than 10 $\mathrm{mm}$ wide; plagioclase glomerocrysts as much as $2 \mathrm{~cm}$ in diameter; olivine phenocrysts; no clinopyroxene phenocrysts; normal magnetic polarity (Choiniere and Swanson, 1979); crops out a few miles northwest of Ice Harbor Dam; feeder dikes northeast of Ice Harbor Dam on the south slope of the Saddle Mountains at the junction of the Saddle Gap and Eagle Lakes segments (Reidel, 1984, 1987).

$\mathrm{N}_{\text {sem }}$

Elephant Mountain Member (upper Miocene)--Two nearly aphyric basalt flows (Swanson and others; 1980) with normal to transitional magnetic polarity (Rietman, 1966; Choiniere and Swanson, 1979; Reidel and Fecht, 1981) and an average total thickness of about $30 \mathrm{~m}$; present in the westernmost part of the map area; isotopically dated at $10.5 \mathrm{Ma}$ by Mckee and others (1977) and at $9.4+/-0.7 \mathrm{Ma}$ and $10.7+/-0.8 \mathrm{Ma}$ by stoffel (1984).

Upper flow (Ward Gap flow) black; weathers reddish brown; fine- to coarse-grained, locally diktytaxitic and generally coarser grained than lower flow; abundant microphenocrysts of plagioclase; vesicular flow top; thin entablature; well-developed colonnade with columns as much as $2 \mathrm{~m}$ in diameter; vesicle sheets that cause platy jointing; locally pillowed base (Myers and others, 1979).

Lower flow (Elephant Mountain flow) black to dark gray; weathers reddish gray; fine-grained to glassy, locally diktytaxitic; felty texture caused by abundant plagioclase microphenocrysts; thick, locally tiered entablature caused by horizontal vesicle sheets; well-developed colonnade with 1.0- to 2.0-m-diameter columns; local pillows and vesicle cylinders (Myers and others, 1979). 
$\mathrm{Mv}_{\mathrm{sp}}$

Pomona Member (middle Miocene)--Basalt, with small phenocrysts of plagioclase (generally less than $5 \mathrm{~mm}$ long), clinopyroxene, and olivine; plagioclase phenocrysts commonly wedge-shaped; locally contains large clots (as much as $100 \mathrm{~mm}$ or more across) of plagioclase, pyroxene (including very rare hypersthene), and olivine thought by Swanson and others (1980) to have formed during crystallization after eruption; reversed magnetic polarity (Choiniere and Swanson, 1979; Reidel and others, 1984); occurs as more nearly sheet-like flow $(s)$; average thickness in map area is

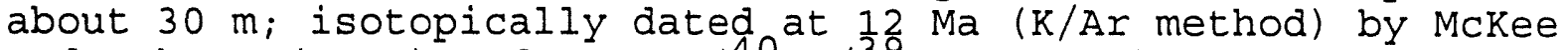
and others $(1977)$ and $12 \mathrm{Ma}\left(40_{\mathrm{Ar}}\right)^{39} \mathrm{Ar}$ method) (S. P. Reidel, unpublished data, 1991). Description from Swanson and others, 1980 .

Myers and others (1979) describe two flow units. Upper flow: black to gray-black; weathers gray; fine- to mediumgrained; phyric with plagioclase and olivine phenocrysts as much as $5 \mathrm{~mm}$ across; localiy microvesicular to diktytaxitic; welldeveloped entablature, generally with fanning columns; poorly to well-developed colonnade of 1-m-diameter columns. Lower flow: blue-black; weathers black-gray; fine- to medium-grained; plagioclase phenocrysts as much as $1 \mathrm{~cm}$ across; sparse olivine phenocrysts as much as $0.5 \mathrm{~mm}$ across; glomerocrysts of plagioclase and pyroxene as much as $2 \mathrm{~cm}$ across; well-developed entablature; hackly jointing and fanning columns.

$\mathrm{Mv}_{\text {se }}$

Esquatzel Member (middle Miocene)--Basalt flows; blue-black; weathers brownish; fine grained, plagioclase phyric to glomerophyric as much as $1.5 \mathrm{~cm}$ across; locally dikiyxtaxtic with vesicle pipes and sheets; well developed entablature with hackly jointing; well developed colonnade with $1 \mathrm{~m}$ diameter columns; normal magnetic polarity (Choiniere and Swanson, 1979; Reidel and Fecht, 1981); greatest thickness is $30 \mathrm{~m}$ in coreholes in Cold Creek syncline but thins and pinches out onto anticlinal ridges (Reidel and Fecht, 1981; Reidel and others, 1989b); restriced to central and northern parts of map area; crops out on Gable Mountain and Gable Butte (T13N, R25 and 26E), and on Yakima Ridge; older than the Pomona Member (Mckee and others, 1977) and younger than the Asotin Member (13 Ma, Reidel and Fecht, 1987, p. 666); no known feeder dikes but presence in snake River canyon suggests vent area near Clarkston, Washington; consists of at least two flow units (Reidel and Fecht, 1981); can easily be distinguished by higher $\mathrm{TiO}_{2}$ and $\mathrm{P}_{2} \mathrm{O}_{5}$ than overlying Pomona Member and underlying Asotin Member. Descriptions from Reidel and Fecht (1981), Swanson and others, (1979); Myers and others, (1979).

$\mathrm{Mv}_{\text {sa }}$ 
Asotin Member (middle Miocene)--Basalt flow; black to grey; weathers grey; glassy, fine- to medium-grained; aphyric with microphenocrysts of olivine up to $0.05 \mathrm{~cm}$ and rare plagioclase phenocrysts; lccally ophitic and diktytaxitic; well-developed entablature with hackly jointing. and fanning columns; well developed colonnade with columns as much as $1 \mathrm{~m}$ in diameter; normal magnetic polarity (Choiniere and Swanson, 1979; Reidel and Fecht, 1981); no thicker than $30 \mathrm{~m}$ in map area; pinches out to south onto constructive topography of the Esquatzel Member and thins onto Umtanum Ridge (Reidel and Fecht, 1981; Reidel and others, 1989b); restricted to extreme northern part of map area; crops out on Gable Mountain (NE $1 \backslash 4$ sec. 22, T13N, R26E); younger than underlying Wilbur Creek Member and older than overlying Esquatzel Member; no known feeder dike but present as far east as Idaho; locally mixed with wilbur Creek Member and basalt of Lapwai to form Huntzinger flow indicating nearly simultaneous eruption of the three flows (Reidel and Fecht, 1987).

Descriptions from Reidel and Fecht (1981; 1987), Swanson and others (1979); Myers and others (1579).

$M v_{\text {wC }}$

Wilbur Creek Member (middle Miocene)--Basalt flow;black to blueblack; weathers grey-black; fine- to medium-grained; aphyric with rare microphenocrysts of plagioclase; thin entablature with welldeveloped colonnade with columns 0.5 to $1.0 \mathrm{~m}$ in diameter; locally developed hackly jointing and pillows at base of flow; normal magnetic polarity (Choiniere and Swanson, 1979; Reidel and Fecht, 1981); approximately $10 \mathrm{~m}$ thick in map area; exposed on Umtanum Ridge ( $\mathrm{SW} 1 \backslash 4$ sec. 24, T13N, R23E) and Yakima Ridge as part of intracanyon flow along flow front of Umatilla flow (Reidel and Fecht, 1986); youngex than underlying Umatilla Member and older than overlying Asotin Member; no know feeder dike; locally mixed with Asotin Member and basalt of Lapwai to form Huntzinger flow indicating nearly simultaneous eruption of the three flows (Reidel and Fecht, 1987). Descriptions from Reidel and Fecht (1981; 1987), Swanson and others (1979); Myers and others (1979).

Av su

Umatilla Member (middle Miocene)--Basalt flows; black; weathers yellow-orange; glassy to very fine grained; locally mediumgrained; sparse plagioclase phenocrysts as much as $0.7 \mathrm{~cm}$ across; well-developed entablature (normally 80 percent of flows) with hackly jointing; local colonnade; normal magnetic polarity

(Rietman, 1966); present along the Walla Walla and Columbia River valleys in the southwest part of the map area; older than Asotin Member (13 Ma, Reidel and Fecht, 1987, p. 666) and younger than Piriest Rapids Member (14.5 Ma, Tolan and others, 1989). Consists of an upper subunit called the basalt of Sillusi and a lower subunit called the basilt of Umatilla, which has lower $\mathrm{P}_{2} \mathrm{O}_{5}$ and higher $\mathrm{TiO}_{2}$ contents than the basalt of Sillusi (S. P. Reidel, 
written commun., 1990). Both subunits are locally mixed together indicating simultaneous eruption of flows (Reidel and Fecht, 1987). Description compiled from: Myers and others, 1979; Swanson and others, 1980.

Wanapum Basalt

Mver

Priest Rapids Member (middle Miocene)--Basalt flows; black, weather rusty brown; fine- to medium-grained, aphyric; diktytaxitic; local diabasic texture in upper part of flow; lower flows generally coarser grained than upper flow; scattered but prominent plagioclase phenocrysts generally less than $5 \mathrm{~mm}$ long but rarely as much as $10 \mathrm{~mm}$ long; olivine phenocrysts 0.5 to $1 \mathrm{~mm}$ in diameter; well-developed colonnade with 0.5-1.5-m-diameter columns; upper flow with well-developed, hackly jointed entablature; reversed magnetic polarity (Rietman, 1966); total thickness 30-40 m; present west of the snake River in the northern part of the map area; isotopic age $14.5 \mathrm{Ma}$ (Tolan and others, 1989). Upper flow is designated the basalt of Lolo and the lower flows the basalt of Rosalia; the Lolo has higher Mgo and lower $\mathrm{TiO}_{2}$ contents than the Rosalia (Swanson and others, 1979, p. G11, G37). Description compiled from: Myers and others, 1979; Swanson and others., 1980.

$M v_{\text {wr }}$

Roza Member (middle Miocene)--Basalt flow(s); gray-black, weather reddish-brown; fine- to medium-grained; consistently contains several percent discrete (in places clotted) plagioclase phenocrysts averaging nearly $10 \mathrm{~mm}$ across; locally diktytaxitic; well-developed colonnade with columns as much as $1 \mathrm{~m}$ in diameter; columns locally pinch and swell; one or two flows in the map area but as many as seven flows near vents to the east of the map area (Martin, 1989); transitional to reversed magnetic polarity (Choiniere and Swanson, 1979); average thickness about $40 \mathrm{~m}$, generally increasing westward across the Columbia Basin; present throughout the map area; older than Priest Rapids Member (14.5 $\mathrm{Ma}$, Tolan and others; 1989) and younger than Frenchman Springs Member (15.3 Ma, Tolan and others, 1989). The Roza Member, because of its large and nearly ubiquitous plagioclase phenocrysts and wide distribution, is a key marker across much of the Columbia Basin. Description compiled from: Myers and others, 1979; Swanson and others, 1980.

Mv wes

Frenchman Springs Member (middle Miocene)--Five or more basalt flows; second lowest flow(s) (basalt of Ginkgo) generally more 
phyric than middle and upper flows; normal to excursional magnetic polarity (Figure 5); thickness as much as $250 \mathrm{~m}$ in the Pasco Basin; present in most of the map area; feeder dikes east of the map area; isotopic age $15.3 \mathrm{Ma}$ for basalt of Sand Hollow, a flow in the middle of the member and 15.6 for the basalt of Ginkgo (Tolan and others, 1989); Beeson and others (1985) defined the informal Frenchman springs subunits shown on Figure 5. Aphyric flows: gray-black; fine grained; well-developed entablatures with hackly jointing; colonnades with 1.5-2.0-mdiameter columns; locally pillowed bases. Phyric flow(s): grayblack; weather reddish-gray; fine-to medium-grained; abundant plagioclase phenocrysts and glomerocrysts; thin entablature; well-developed colonnade with 0.5-1.5-m-diameter columns. Description compiled from: Myers and others, 1979; Swanson and others, 1980 .

\section{Grande Ronde Basalt}

The middle Miocene Grande Ronde Basalt makes up 87 percent of the volume of the Columbia River Basalt Group (Tolan and others, 1989). Flows of the Grande Ronde Basalt are generally aphyric and fine grained. The groundmass contains plagioclase, augite, and pigeonite. Plagioclase phenocrysts are sparse, and microphenocrysts of orthopyroxene, pigeonite, and olivine are rare. Blocky jointing is common, but entablature and columnar jointing are also present. At least 120 flows are known; these are divided into 17 informal units; the total thickness is about $4 \mathrm{~km}$ (Reidel and others, 1989a, p. 23, 36; Fig. 5). In the Blue Mountains, east of the map area, the Grande Ronde has a maximum aggregate thickness of more than $1,235 \mathrm{~m}$, and the maximum thickness exposed at a single locality is about $1,050 \mathrm{~m}$. The formation is divided into four magnetostratigraphic units, but only are the two upper units exposed in the map area. The $\mathrm{N}_{2}$ magnetostratigraphic unit is exposed along the north face of the Saddle Mountains, Frenchman Hills, and Umtanum Ridge. Feeder dikes are exposed to to the east: The Grande Ronde conformably overlies the Imnaha Basalt, and it is overlain by the Wanapum Basalt, commonly with an intervening saprolite or sedimentary interbed. The formation is isotopically dated at about 15.6 to $16.9 \mathrm{Ma}$ (Baksi, 1989, p. 109; age information summarized by Reidel and others, 1989a, p. 24-25). The type locality is in the canyon of the Grande Ronde River north of the mouth of Joseph Creek (secs. 21-23, T. 7 N., R. 46 E.) in the Clarkston 1:100,000-scale quadrangle (Reidel and others, 1992).

$$
\text { AvigN2 Upper flows of normal magnetic polarity. }
$$

${ }^{M} v_{\text {gR2 }} \quad$ Upper flows of reversed magnetic polarity. 
Description compiled from: Reidel, 1983; Hooper and others, 1985; Reidel and others, 1989a; Swanson and others, 1980; Swanson and Wright, 1983; this report.

\section{REFERENCES CITED}

Aguirre, Emiliano; Pásini, Giancarlo, 1985, The PliocenePleistocene boundary: Episodes, v. 8, no. 2, p. 116-120.

Baksi, A. K., 1989, Reevaluation of the timing and duration of extrusion of the Imnaha, Picture Gorge, and Grande Ronde Basalts, Columbia River Basalt Group. In Reidel, S.P.; Hooper, P. R., editors, Volcanism and tectonism in the Columbia River flood-basalt province: Geological society of America Special Paper 239, p. 105-111.

Beeson, M. H.; Fecht, K. R.; Reidel, S. P.; Tolan, T. L., 1985, Regional correlations within the Frenchman springs Member of the Columbia River Basalt Group: New insights into the middle Miocene tectonics of northwestern Oregon: Oregon Geology, v. 47, no. 8, p. 87-96.

Choiniere, S. R.; Swanson, D. A., 1979, Magnetostratigraphy and correlation of Miocene basalts of the northern Oregon coast and Columbia Plateau, southeast Washington: American Journal of Science, v. 279, no. 7, p. 755-777.

Dalrymple, G. B., 1979, Critical tables for conversion of K-Ar ages from old to new constants: Geology, v. 7, no. 11, p. $558-560$.

Fecht, K. R.; Reidel, S. P.; Taliman, A. M., 1987, Paleodrainage of the Columbia. River on the Columbia Plateau of Washington State--A summary: in Schuster, J. E., ed., Selected papers on the geology of Washington, Washington Division of Geology and earth Resources Bulletin 77, p. 219-248.

Foley, L. L., 1982, Quaternary chronology of the Palouse loess near Washtucna, eastern Washington: Western Washington University Master of Science thesis, $137 \mathrm{p}$. 
Grolier, M. J.; Bingham, J. W., 1971, Geologic map and sections of parts of Grant, Adams, and Franklin Counties, washington: U.S. Geological Survey Miscellaneous Geologic Investigations Map I-589, 6 sheets, scale 1:62,500. (Sheet 5)

Gulick, C. W., compiler, 1990a, Geologic map of the Moses Lake 1:100,000 quadrangle, Washington: Washington Division of Geology and Earth Resources Open File Report 90-1, 9 p., 1 plate.

Gulick, C. W., compiler, 1990b, Geologic map of the Ritzville 1:100,000 quadrangle, Washington: Washington Division of Geology and Earth Resources. Open File Report 90-2, 7 p., 1 plate.

Hooper, P. R.; Webster, G. D.; Camp, V. E., 1985, Geologic map of the Clarkston 15 minute quadrangle, Washington and Idaho: Washington Division of Geology and Earth Resources Geologic Map GM-31, 11 p., 1 plate, scale 1:48,000.

Kittleman, L. R., 1973, Mineralogy, correlation, and grain-size distributions of Mazama tephra and other postglacial pyroclastic layers, Pacific Northwest: Geological Society of America Bulletin, v. 84, no. 9, p. 2957-2980.

Laval, W. N., 1956, Stratigraphy and structural geology of portions of south-central Washington: University of Washington Doctor of Philosophy thesis, 223 p., 11 plates. (Plate XXXI, scale 1:62,500.)

Iindsey, K. A., 1991, Revised stratigraphy for the Ringold Formation, Hanford site, south-central, Washington: Westinghouse Hanford Co. WHC-SD-EN-EE-004, 12 p.

Martin, B. S., 1989, The Roza Member, Columbia River Basalt Group; Chemical stratigraphy and flow distribution. In Reidel, S. P.; Hooper, P. R., editors, Volcanism and tectonism in the Columbia River flood-basalt province: Geological Society of America Special Paper 239, p. 85-104.

McDonald, E. V.; Busacca, A. J., 1989, Record of pre-late Wisconsin floods and of late Wisconsin flood features in the Cheney-Palouse scabland--Trip C. In Joseph, N. L.; and others, editors, Geologic guidebook for Washington and adjacent areas: Washington Division of Geology and Earth Resources Information Circular 86, p. 337-346.

McKee, E. H.; Swanson, D. A.; Wright, T. L., 1977, Duration and volume of Columbia River basalt volcanism, Washington, Oregon, and Idaho [abstract]: Geological Society of America Abstracts with Programs, v. 9, no. 4, p. 463-464.

Montanari, Alessandro; Drake, Robert; Bice, D. M.; Alvarez, Walter; Curtis, G. H.; Turrin, B. D.; DePaolo, D. J., 1985, 
Radiometric time scale for the upper Eocene and Oligocene based on $\mathrm{K} / \mathrm{Ar}$ and $\mathrm{Rb} / \mathrm{Sr}$ dating of volcanic biotites from the pelagic sequence of Gubbio, Italy: Geology, v. 13, no. 9, p. 596-599.

Mullineaux, D. R.; Wilcox, R. E.; Ebaugh, W. F.; Fryxell, Roald; Rubin, Meyer, 1978, Age of the last major scabland flood of the Columbia Plateau in eastern Washington: Quaternary Research, v. 10, no. 2, p. 171-180.

Myers, C. W.; Price, S. M.; and others, 1979, Geologic studies of the Columbia Plateau--A status report: Rockwell Hanford Operations RHO-BWI-ST-4, 541 p., 53 plates. (Plates II-7 and II-16, scale 1:250,000; Plate III-1 (12 sheets), scale $1: 62,500)$

Newcomb, R. C., 1965, Geology and ground-water resources of the Walla Walla River basin, Washington-Oregon: Washington Division of Water Resources Water-Supply Bulletin 21, 151 p., 4 plates. (Geologic map: Plate 1, scale 1:95,800)

Reidel, S. P., 1983, Stratigraphy and Petrogenesis of the Grande Ronde Basalt from the Deep canyon Country of Washington Oregon, and Idaho: Geological Society of America Bulletin, v.94., p.519-542.

Reidel, S. P., 1984, The Saddle Mountains -- the evolution of an anticline in the Yakima Fold Belt: American Journal of Science, v. 284, no. 8, p. 942-978.

Reidel, S. P., 1987, Geologic Map of the Saddle Mountains, Southcentral Washington: Washington Division of Geology and Earth Resources, GM-37, 5 plates, scale 1:40,000.

Reidel, S. P.; Fecht K. R.; 1981, Wanapum and Saddle Mountains Basalts of the Cold Creek Sybcline: in Myers, C. W. and Price, S. M., Subsurface Geology of the Cold Creek Syncline, Rockell Hanfford Operations Report RHO-BWI-ST-14, p. 3-1 to $3-45$.

Reidel, S. P.; Fecht K. R., 1987; The Huntzinger flow: Evidence of surface mixing of the Columbia River Basalt and its petrogenetic implications: Geological Society of America Bulletin, v. 98, No. 6, p. 664-677.

Reidel, S. P.; Scott G. R.; Bazard D. R.; Cross R. W., Dick, Brian, 1984, Post-12 million year clockwise rotation in the central Columbia Plateau, Washington: Tectonics, v. 3, no. 2 , p. 251-273.

Reidel, S.P.; Tolan T. L.; Hooper P. R.; Beeson M. H.; Fecht K. R.; Bentley R. D., Anderson, J. L., 1989a, The Grande Ronde Basalt, Columbia River Basalt Group - stratigraphic descriptions and correlations in Washington, Oregon, and 
Idaho, in Reidel, S.P., and.Hooper, P.R., eds., Volcanism and tectonism in the Columbia River flood-basalt province: Boulder, Colorado, Geological Society of America Special Paper 239, p. 21-53.

Reidel, S.P.; Fecht, K. R; Hagood, M. C.; and Tolan, T. L., 1989b, The geologic evolution of the central Columria Plateau, in Reidel, S.P., and Hooper, P.R., eds., Volcanism and tectonism in the Columbia River flood-basalt province: Boulder, Colorado, Geological Society of America Special Paper 239, p. 247-264.

Reidel, S. P.; Hooper, P. R.; Webster G. D.; Camp V. E., 1992, Geologic Map of Southeastern Asotin County, Washington: Washington Division of Geology and Earth Resources Gelogic Map GM-40.

Rietman, J. D., 1966, Remanent magnetization of the late Yakima Basalt, Washington State: Stanford University Doctor of Philosophy thesis, $87 \mathrm{p}$.

Rigby, J. G.; Othberg, K. L.; Campbell, N. P.; Hanson, L. G.; Kiver, E. P.; Stradling, D.'F.; Webster, G. D., 1979, Reconnaissance surficial geologic mapping of the late Cenozoic sediments of the Columbia Basin, Washington: Washington Division of Geology and Earth Resources Open File Report 79-3, 94 p., 11 plates. (Plate 7, scale 1:250,000, is the same map as Campbell and others, 1979.)

Ringe, L. D., 1970, Sub-Loess basalt topography in the Palouse Hills, southeastern Washington: Geological society of America Bulletin, v. 81, no. 10, p. 3049-3059.

Salvador, Amos, 1985, Chronostratigraphic and geochronometric scales in COSUNA stratigraphic correlation charts of the United States: American Association of Petroleum Geologists Bulletin, v. 69 , no. 2, p. 181-189.

Stoffel, K. L, 1984, Geology of the Grande Ronde lignite field, Asotin County, Washington: Washington Division of Geology and Earth Resources Report of Investigations 27,79 p., 1 plate, scale 1:48,000.

Swanson, D. A.; Helz, R. T., 1979, Bedrock geologic map of the vent system for the Ice Harbor Member of the Saddle Mountains Basalt, Ice Harbor Dam-Basin City area, southeast Washington: U.S. Geological Survey Open-File Report 79-292, 8 sheets. (Geologic maps: Sheets $4-8$, scale 1:24,000.)

Swanson, D. A.; Wright, T. L.; Helz, R. T., 1975, Linear Vent Systems and Estimated Rates of magma Production and Eruption for the Yakima Basalt on the Columbia Plateau: American Journal of Science, v. 275, p. 977-905. 
Swanson, D. A.; Wright, T. L.; Camp, V. E.; Gardner, J. N.; Helz, R. T.; Price, S. M.; Reidel, S. P.; Ross, M. E., 1980, Reconnaissance geologic map of the Columbia River Basalt Group, Fullman and Walla Walla quadrangles, southeast Washington and adjacent Idaho: U.S. Geological Survey Miscellaneous Investigations Series Map I-1139, 2 sheets, scale $1: 250,00$.

Swanson, D. A.; Wright, T. L.; Hooper, P. R.; Bentley, R. D., 1979, Revisions in stratigraphir: nomenclature of the Columbia River Basalt Group: J. S. Geological Survey Bulletin 1457-G, 59 p., 1 plate.

Swanson, D. A.; Wright, T. L., 1983, Geologic map of the Wenaha Tucannon Wilderness, Washington and Oregon: U. S. Geological Survey Miscellaneous Field Studies Map MF-1536, 1 sheet, scale 1:48,000.

Tabor, R. W.; Waitt, R. B., ; Frizzell, V. A., Jr.; Swanson, D. A.; Byerly, G. R.; Bentley, R. D., 1982, Geolc jic map of the Wenatchee $1: 100,000$ quadrangle, central washington: U.S. Geological Survey Miscellaneous Investigations Series Map I$1311,26 \mathrm{p} ., 1$ plate, scale 1:100,000.

Tolan, T. L.; Reidel, S. P.; Beeson, M. H.; Anderson, James Lee; Fecht, K. R.; Swanson, D. A., 1989, Revisions to the estimates of the areal extent and volume of the Columbia River Basalt Group. In Reidel, S. P.; Hooper, P. R., editors, Volcanism and tectonism in the Columbia River flood-basalt province: Geological Society of America Special Paper 239, p. 1-20.

Waggoner, S. Z., compiler, 1990, Geologic map of the Rosalia 1:100,000 quadrangle, Washington-Idaho: Washington Division of Geology and Earth Resources Open File Report 90-7, 20 p., 1 plate.

Waitt, R. B., 1980, About forty last-glacial Lake Missoula jökulhlaups through southern Washington: Journal of Geology, v. 88, no. 6, p. 653-679. 


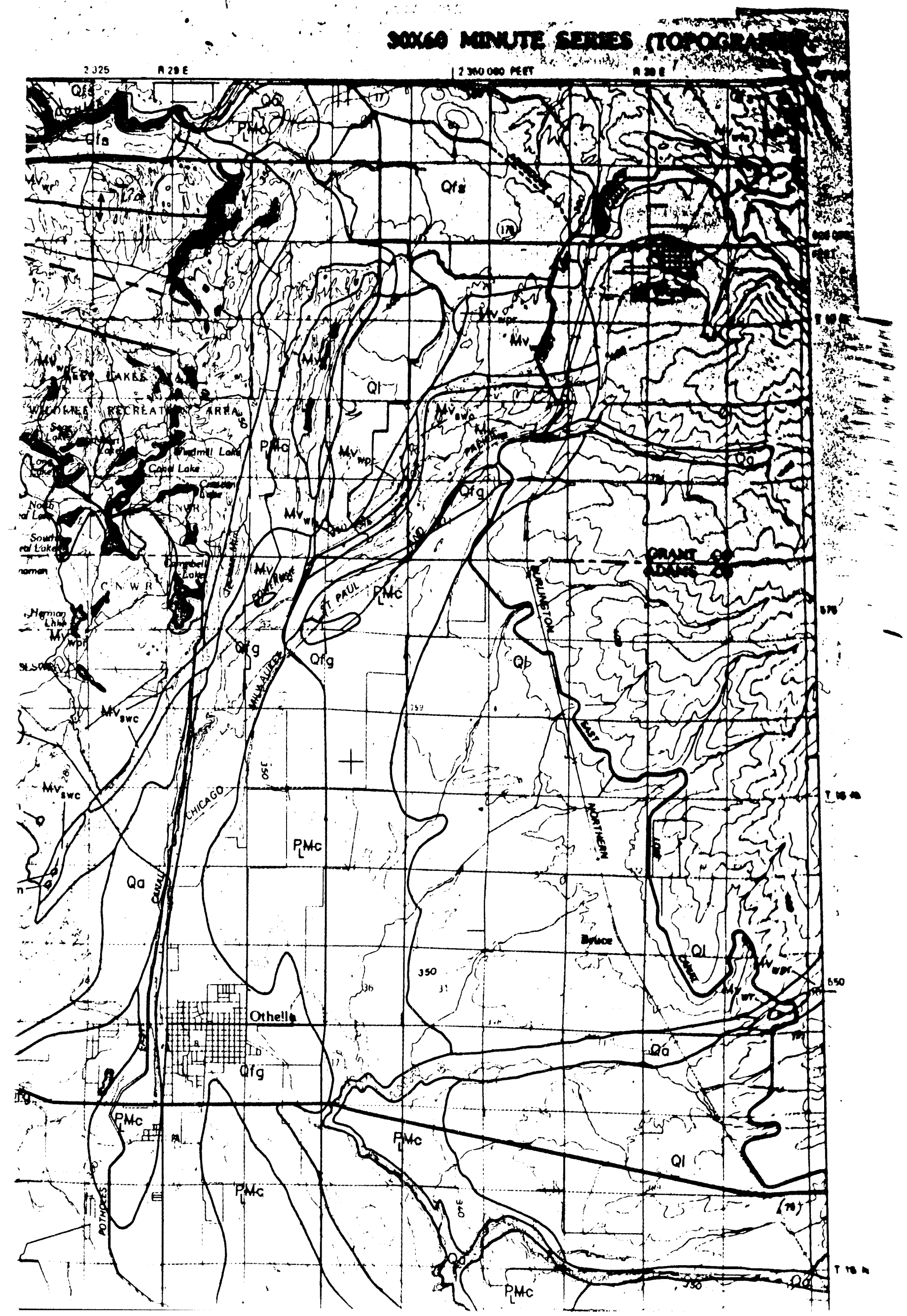




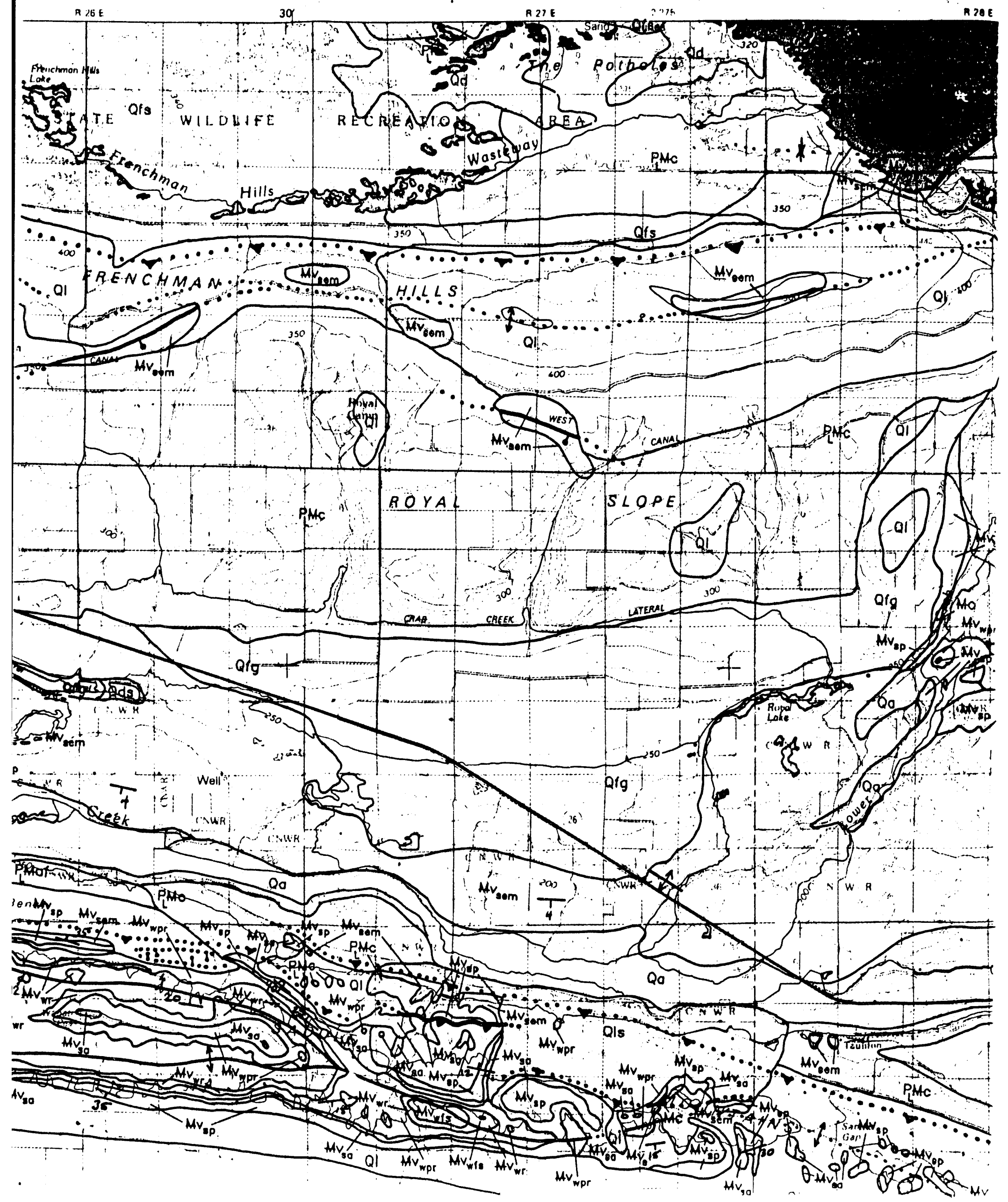




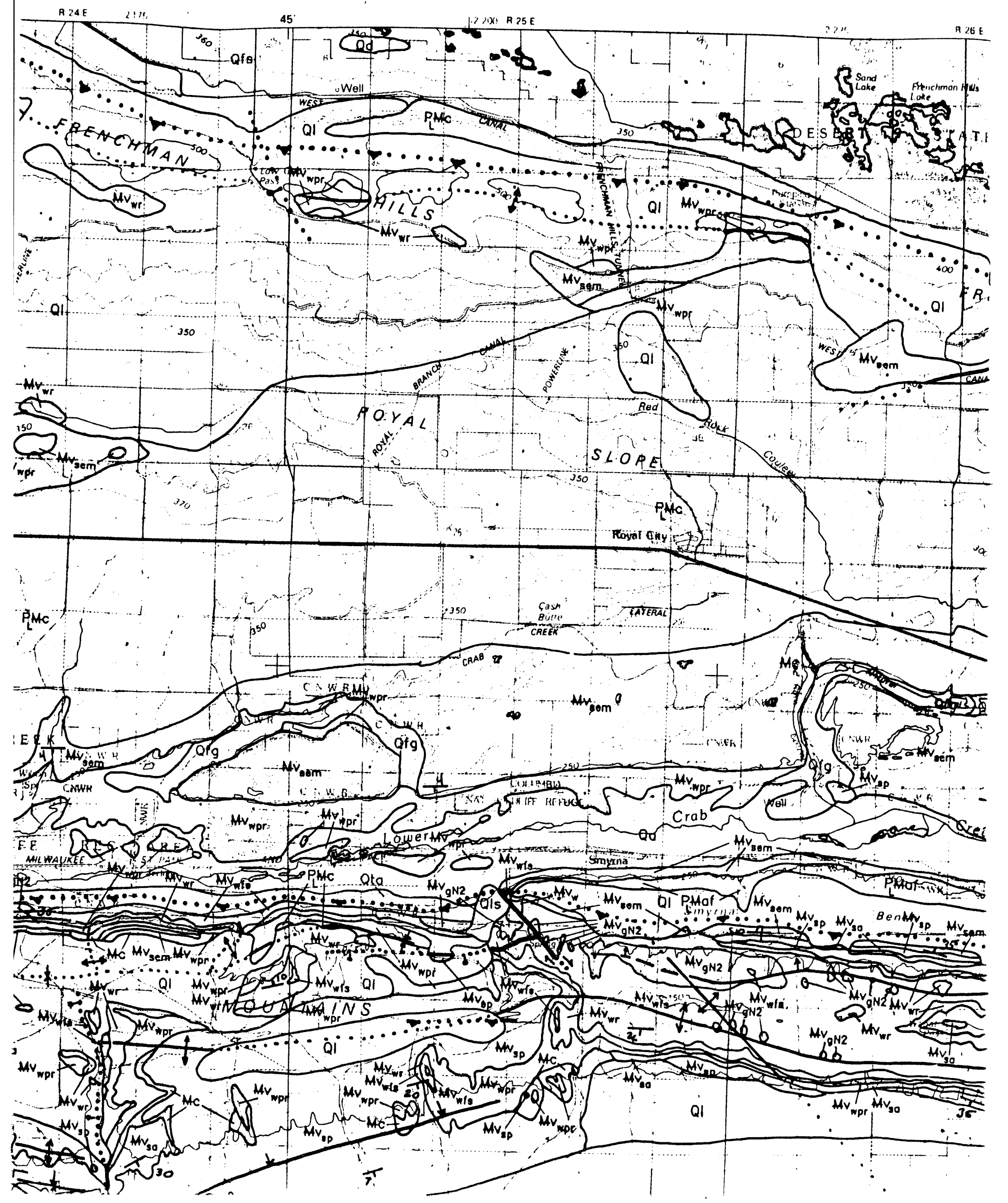




\section{PRIEST RAPIDS, WASHINGTON}

$120^{\circ} 00$

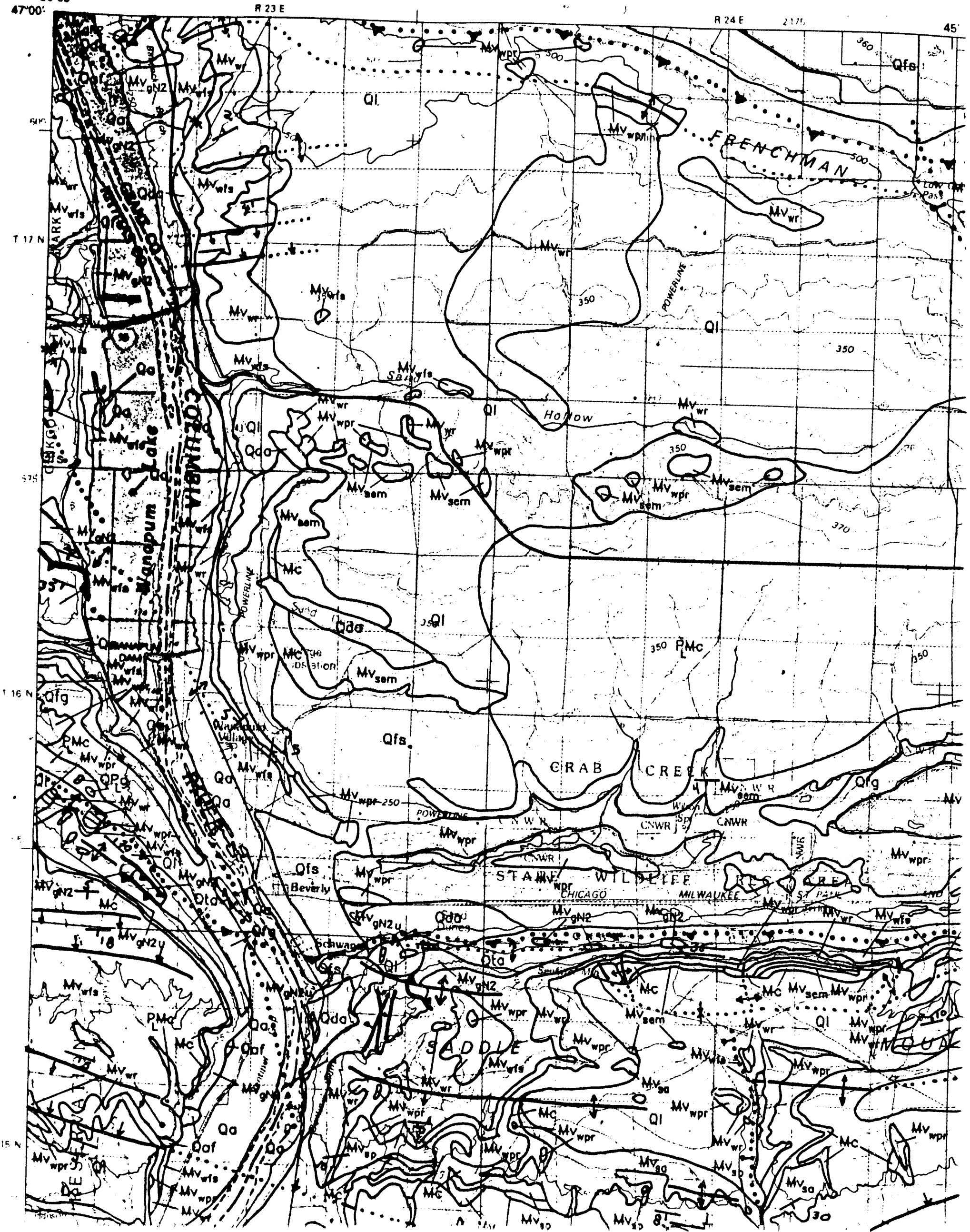




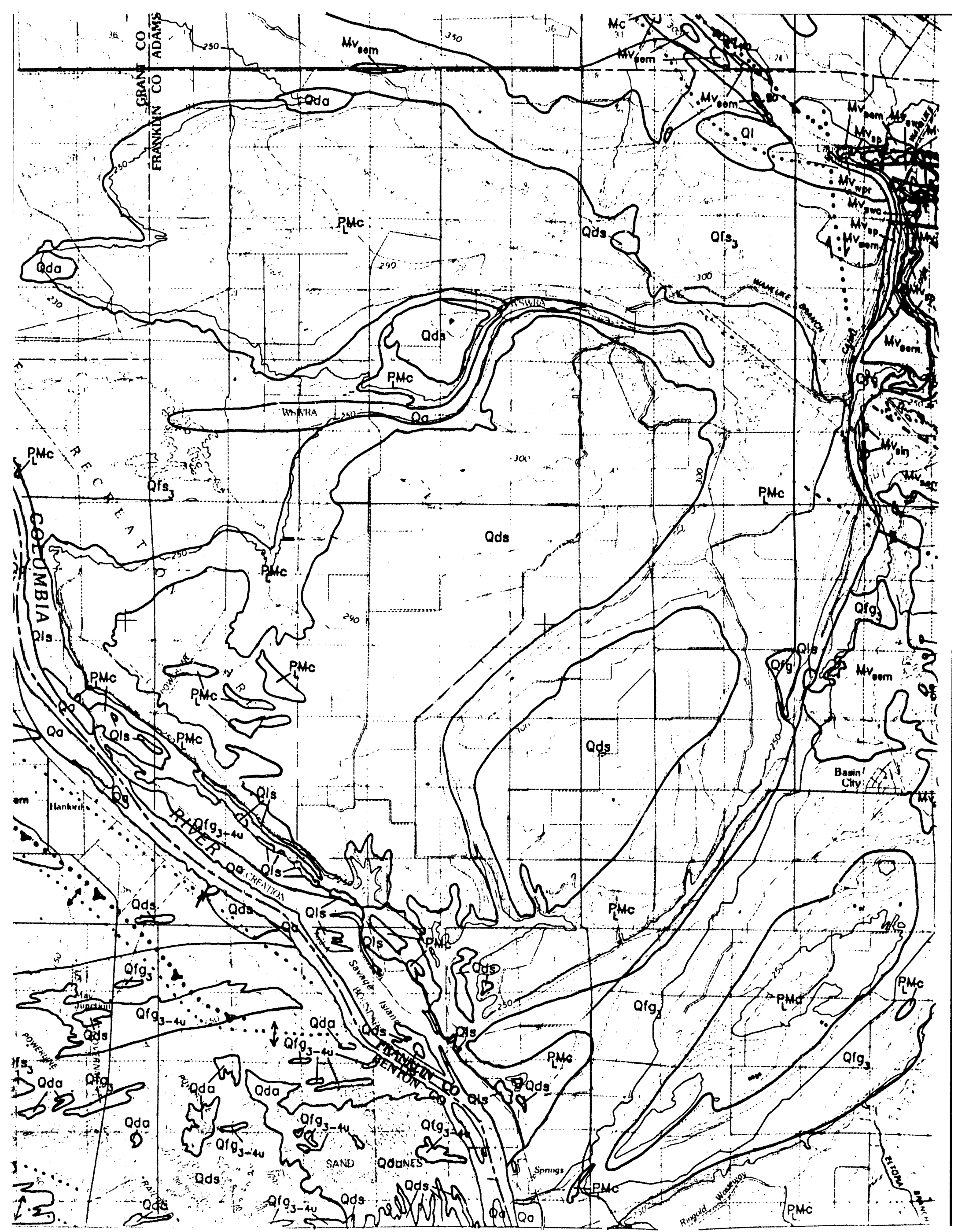




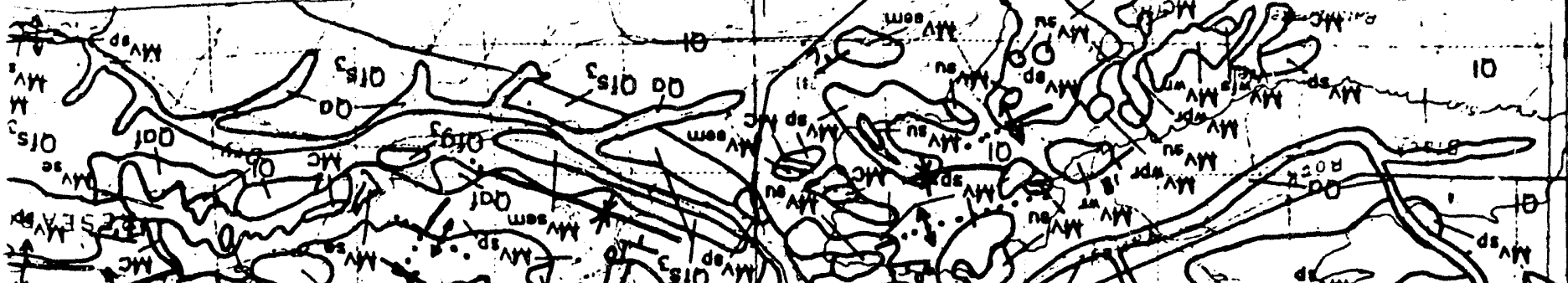

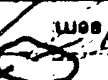

(n)

10 Ff कn

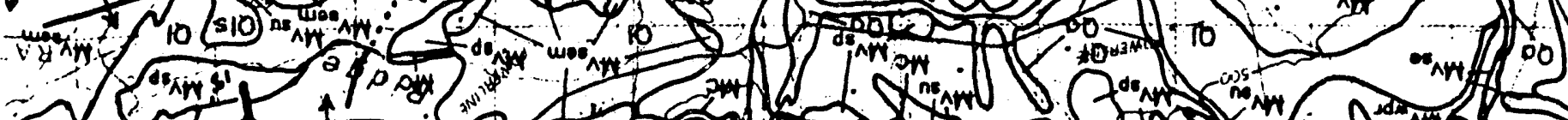
CV F

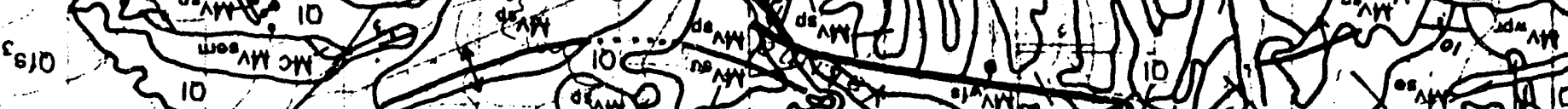

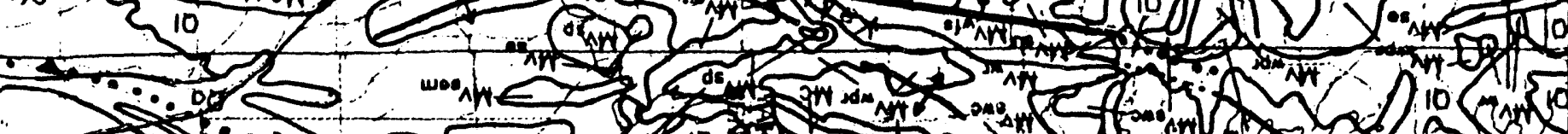
$=2$

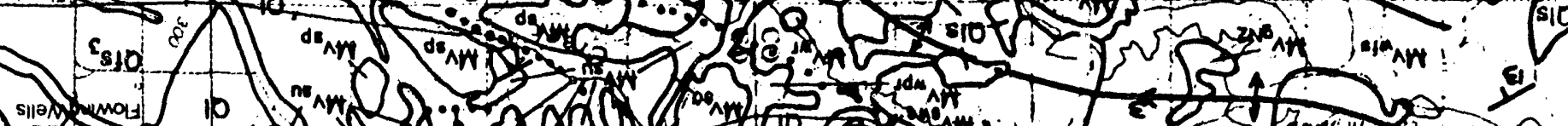
1)

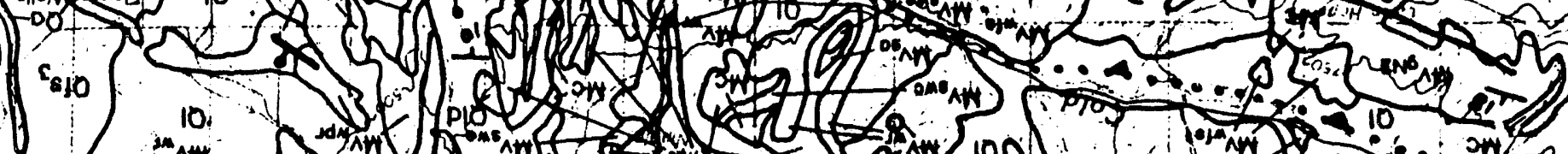
1010 .

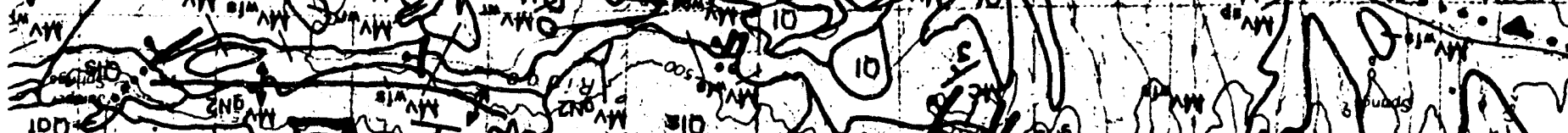

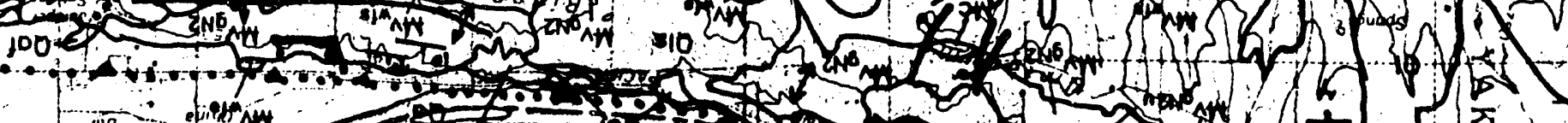

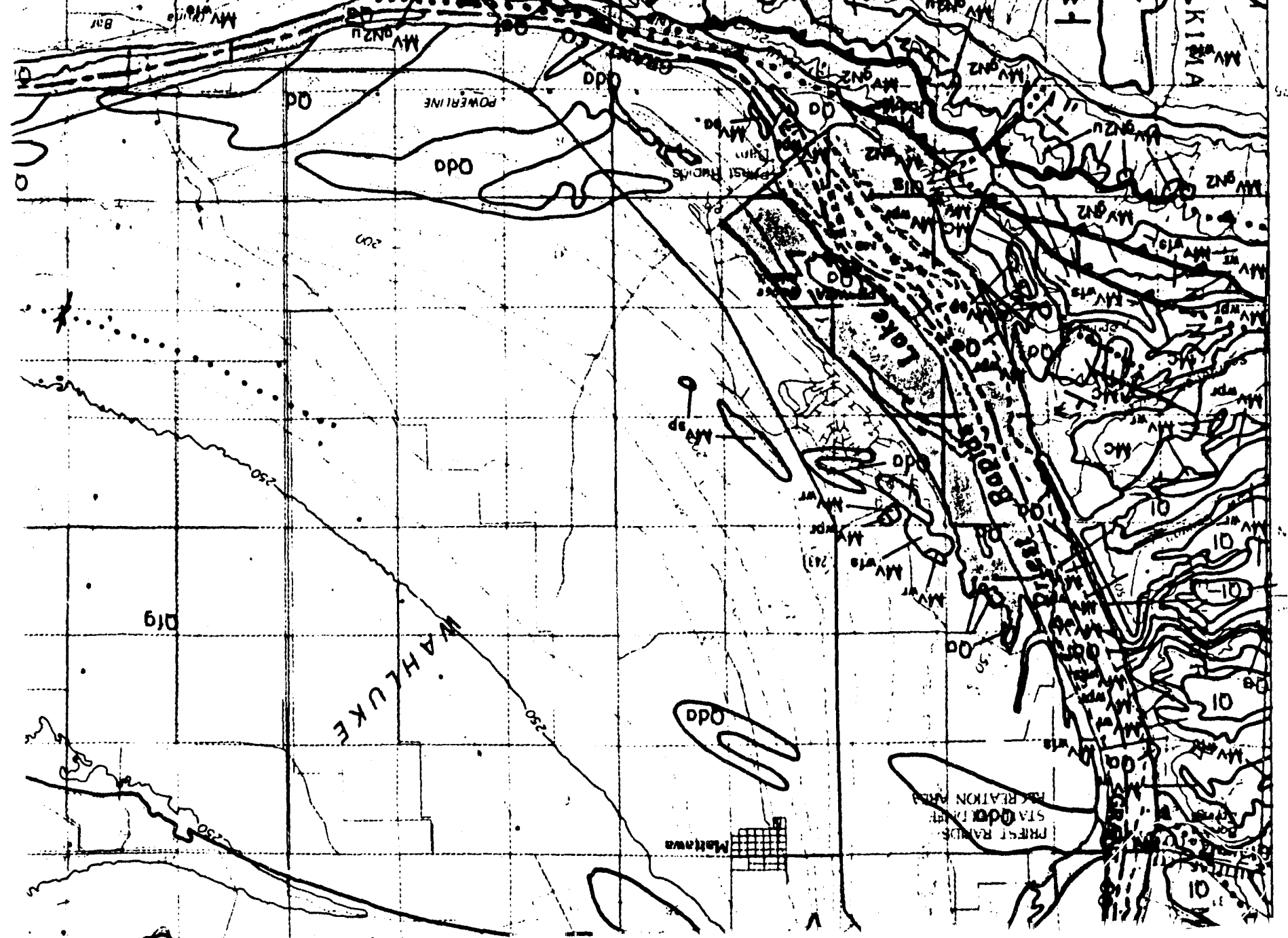




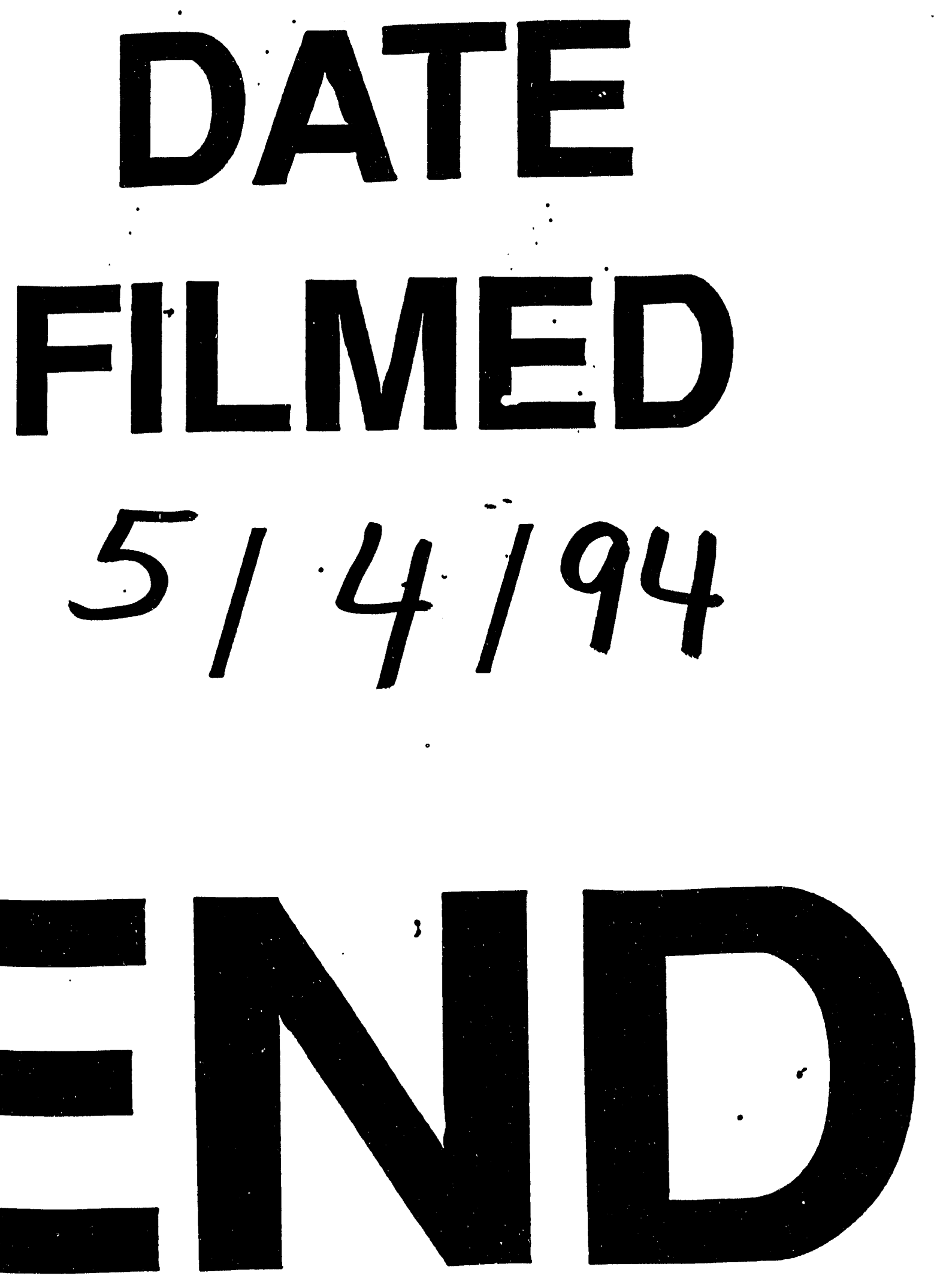


